\title{
USAHA MAKSIMAL MENINGKATKAN PRESTASI BELAJAR SOSIOLOGI DENGAN PEMANFAATAN METODE TANYA JAWAB MULTIARAH SISWA KELAS XI IPS 1 SMA NEGERI 1 KUTA
}

\section{MAXIMUM EFFORT TO INCREASE SOCIOLOGY LEARNING ACHIEVEMENT WITH THE UTILIZATION OF MULTI-WAY Q\&A METHODS FOR CLASS XI IPS 1 SMA NEGERI 1 KUTA}

\author{
Ni Nyoman Suparni* \\ SMA Negeri 1 Kuta, Badung, Bali, Indonesia \\ *Email Penulis korespondensi: suparnininyoman@gmail.co.id
}

\begin{abstract}
Abstrak
Materi Sosiologi yang disampaikan guru belum dipahami dengan baik. Hal itu telah menyebabkan rendahnya prestasi belajar Sosiologi yang diperoleh siswa. Oleh karena itu diperlukan metode pembelajaran yang tepat untuk mengajarkannya agar mereka mudah dalam menerima pelajaran ini. Pemanfaatan metode tanya jawab multiarah diupayakan untuk dapat meningkatkan prestasi belajar Sosiologi Siswa Kelas XI.IPS 1 semester II tahun pelajaran 2019/2020 SMA Negeri 1 Kuta. Tujuannya, agar prestasi belajar Sosiologi dapat ditingkatkan sesuai dengan Kriteria Ketuntasan Belajar yang diharapkan sebesar 70,00. Untuk mengetahui tingkat keberhasilan pelaksanaan tindakan dilakukan tes prestasi belajar yang kemudian dianalisis secara deskriptif. Kesimpulan dari penelitian ini adalah Pemanfaatan metode tanya jawab multiarah dapat meningkatkan prestasi belajar Sosiologi, dibuktikan dari hasil yang diperoleh pada data awal sampai siklus II yaitu, data awal menunjukkan nilai rata-rata sebesar 65,83 dengan ketuntasan belajar mencapai 38,89\%, siklus I meningkat menjadi 69,92 dengan ketuntasan belajar $69,44 \%$, siklus II meningkat menjadi 81,36 dengan ketuntasan belajar 100\%. Hal itu membuktikan bahwa pemanfaatan metode tanya jawab multiarah dapat meningkatkan prestasi belajar Sosiologi Siswa Kelas XI.IPS 1 semester II tahun pelajaran 2019/2020 SMA Negeri 1 Kuta.
\end{abstract}

Kata-Kata Kunci: Prestasi Belajar; Metode Tanya Jawab Multiarah

\begin{abstract}
Sociology material delivered by the teacher was not well understood. This has led to the low learning achievement of Sociology obtained by students. Therefore, appropriate learning methods are needed to teach them so that they are easy to accept this lesson. The use of the multi-directional question and answer method is sought to be able to improve the learning achievement of Sociology Class XI.IPS 1 semester II students in the 2019/2020 school year of SMA Negeri 1 Kuta. The goal is that Sociology learning achievement can be improved in accordance with the expected Learning Completeness Criteria of 70.00. To determine the level of success of the implementation of the action, a learning achievement test was carried out which was then analyzed descriptively. The conclusion of this study is that the use of the multi-directional question and answer method can improve the learning achievement of Sociology, as evidenced by the results obtained in the initial data until the second cycle, namely, the initial data shows an average value of 65.83 with learning mastery reaching $38.89 \%$, the cycle I increased to 69.92 with $69.44 \%$ learning completeness, the second cycle increased to 81.36 with $100 \%$ learning completeness. This proves that the use of the multidirectional question and answer method can improve the Sociology learning achievement of Class XI.IPS 1 semester II students of the 2019/2020 school year of SMA Negeri 1 Kuta.
\end{abstract}

Keywords: Learning Achievement; Multi-way Question and Answer Method 


\section{PENDAHULUAN}

Pemerintah telah banyak menegaskan dalam Peraturan-peraturan yang intinya agar guru mampu meningkatkan diri, mampu membelajarkan siswanya demi peningkatan mutu pendidikan. Para ahli juga banyak menegaskan dan banyak berharap agar melakukan pembelajaran yang efektif, efisien, menyenangkan mengingat peran guru amat penting dalam pengembangan intelektual, sosial dan emosional serta berperan sebagai kunci penentu menuju keberhasilan dalam mempelajari suatu bidang tertentu.

Pihak guru yang akan melaksanakan proses pembelajaran banyak dituntut terutama agar mereka mau dan mampu melaksanakan pembelajaran mengikuti perubahan jaman yaitu menerapkan teori-teori para ahli. Guru harus mampu menempatkan peserta didik pada posisi sentral. Caranya adalah menempatkan peserta didik sebagai figur sentral dalam pendidikan dengan memberikan kemerdekaan sepenuh-penuhnya untuk berkembang, itulah ide dasar pengembangan konsep Ki Hajar Dewantara. Guru hanya membimbing dari belakang dan selanjutnya mengingatkan siswa kalau sekiranya mengarah pada suatu tindakan yang membahayakan (Tut Wuri Handayani) sambil terus membangkitkan semangat dan memberikan motivasi (Ing Madya Mangun Karsa) dan selalu menjadi contoh dalam perilaku dan ucapannya (Ing Ngarsa Sung Tulada). (http://www.kompas.cetak/0307/21/opini/4455.htm).

Seorang guru harus mampu melaksanakan proses belajar mengajar menggunakan model-model pembelajaran yang terbaru yang sifatnya konstruktivis. Pemanfaatan modelmodel pembelajaran merupakan hal yang sangat penting dalam upaya memajukan suatu bidang tertentu. Model sangat berkaitan dengan teori. Sebelum ada model, dikembangkan terlebih dahulu teori yang mendasari model tersebut, sehingga boleh dikatakan bahwa toeri lebih luas daripada model. Model-model, baik model fisika, model-model komputer, modelmodel matematika, semua mempunyai sifat "jika-maka", dan model-model ini terkait sekali pada teori (Ratna Wilis Dahar, 2016 : 5). Model merupakan suatu analog konseptual yang digunakan untuk menyarankan bagaimana meneruskan penelitian empiris sebaiknya tentang suatu masalah. Jadi model merupakan suatu struktur konseptual yang telah berhasil dikembangkan dalam suatu bidang dan sekarang diterapkan, terutama untuk membimbing penelitian dan berpikir dalam bidang lain, biasanya dalam bidang yang belum begitu berkembang (Ratna Wilis Dahar, 2016: 5).

Segudang harapan telah dikemukakan, sekarang bagaimana kebenaran yang ada di lapangan ? Ternyata kenyataan yang ada di lapangan jauh berbeda yaitu : nilai siswa kelas XI.IPS 1 SMA Negeri 1 Kuta pada semester II tahun pelajaran 2019/2020 baru mencapai rata-rata 65,83 dengan ketuntasan belajar baru mencapai 38,89\%. Kendala-kendala yang ada yaitu: 1) Siswa kebanyakan pasif karena tidak ada tugas yang harus dikerjakan, 2) Siswa terlihat bosan akibat guru terus berceramah, 3) Siswa tidak mampu menguasai beberapa materi yang dijelaskan guru, 4) Siswa kurang mampu dalam melatih soal-soal, 5) Guru masih mengajar dengan pola lama, 6) Guru belum melaksanakan pembelajaran yang kooperatif dan kolaboratif.

Paparan yang sudah disampaikan mengerucut ke sebuah kesenjangan yang harus segera diatasi. Semua kelemahan yang ada, sumber penyebabnya adalah: a) menurunnya etika sopan santun akibat percampuran penduduk yang sangat bervariasi, b) berkurangnya rasa hormat pada orang tua, sehingga bila siswanya disuruh belajar maka jawabannya adalah "nanti saja", c) meningkatkan ketidak jujuran yang diakibatkan oleh kurangnya tauladan dari par apemimpin bangsa dan maraknya korupsi yang mengutamakan kepentingan diri sendiri, d) merosotnya etika kerja, e) banyaknya media-media yang bisa diakses yang menampilkan 
hal-hal yang kurang bermoral seperti perkosaan, perkelahian masal, perkelahian antar etnis, dan lain-lain.

Prestasi belajar yang rendah tersebut merupakan masalah pembelajaran di sekolah ini sehingga peneliti sebagai seorang guru harus mengupayakan cara untuk bisa mengatasinya. Untuk itu dipilihlah metode tanya jawab multiarah sebagai upaya untuk menyelesaikannya. Hal di atas merupakan masalah pembelajaran yang terjadi di sekolah ini yang harus segera dibenahi oleh karenanya penelitian ini perlu segera diupayakan agar masalah tidak berlarutlarut.

Rumusan masalah penelitian bertalian dengan masalah yang dipaparkan pada latar belakang masalah. Untuk itu rumusan masalah penelitian ini adalah: Apakah pemanfaatan metode tanya jawab multiarah dapat meningkatkan prestasi belajar Sosiologi siswa kelas XI.IPS 1 semester II SMA Negeri 1 Kuta tahun pelajaran 2019/2020? Tujuan penelitian yang dapat disampaikan adalah: untuk meningkatkan prestasi belajar Sosiologi siswa kelas XI.IPS 1 semester II SMA Negeri 1 Kuta tahun pelajaran 2019/2020 dengan pemanfaatan metode tanya jawab multiarah. Manfaat dilaksanakannya PTK adalah: Untuk meningkatkan prestasi belajar Sosiologi, Pengembangan keterampilan guru yang bertolak dari kebutuhan untuk menanggulangi berbagai permasalahan pembelajaran aktual yang dihadapi di kelasnya.

Prestasi belajar adalah sebuah kalimat yang terdiri dari dua kata yaitu prestasi dan belajar. Antara kata prestasi dan belajar mempunyai arti yang berbeda. Oleh karena itu, sebelum pengertian prestasi belajar, ada baiknya pembahasan ini diarahkan pada masingmasing permasalahan terlebih dahulu untuk mendapatkan pemahaman lebih jauh mengenai makna kata prestasi dan belajar. Hal ini juga untuk memudahkan dalam memahami lebih mendalam tentang pengertian prestasi belajar itu sendiri. Di bawah ini akan dikemukakan beberapa pengertian prestasi dan belajar menurut para ahli.

Hamalik (2015:68) menyatakan bahwa Prestasi belajar merupakan sesuatu yang dibutuhkan seseorang untuk mengetahui kemampuan setelah melakukan kegiatan yang bersifat belajar, karena prestasi adalah hasil belajar yang mengandung unsur penilaian, hasil usaha kerja dan ukuran kecakapan yang dicapai suatu saat.

Menurut Marsun dan Martaniah (dikutif dari Tjundjing, 2016:71) berpendapat bahwa prestasi belajar merupakan hasil kegiatan belajar, yaitu sejauh mana peserta didik menguasai bahan pelajaran yang diajarkan, yang diikuti oleh munculnya perasaan puas bahwa ia telah melakukan sesuatu dengan baik. Hal ini berarti prestasi belajar hanya bisa diketahui jika telah dilakukan penilaian terhadap hasil belajar siswa.

Menurut Sukardi (dalam Qory, 2015:26), menurutnya prestasi belajar sebagai taraf prestasi yang dicapai dari bermacam-macam pelajaran yang telah diikuti.

Berdasarkan beberapa pendapat di atas dapat disimpulkan bahwa prestasi belajar merupakan hasil yang dicapai oleh individu setelah mengalami proses belajar dalam jangka waktu tertentu. Prestasi belajar yang ditampilkan dengan nilai atau angka dibuat guru berdasarkan pedoman penilaian pada masing-masing siswa berbeda, berdasarkan tingkat penguasaan kompetensi yang telah ditetapkan.

Rogers dengan teori pendidikan humanistiknya, mengemukakan prinsip-prinsip belajar yang diidentifikasikan sebagai sentral dari filsafat pendidikannya (Djiwandono, 2016: 184-186) sebagai berikut: Keinginan untuk belajar (the desire to learn), Belajar secara signifikan (significant learning), Belajar tanpa ancaman (learning without threat), Belajar atas inisiatif sendiri (self-initiated learning) dan Belajar dan berubah (learning and change)

Slameto (2014: 3) berpendapat ciri-ciri perubahan tingkah laku sebagai hasil belajar adalah :1) perubahan secara sadar; 2) perubahan bersifat kontinyu dan fungsional; 3) perubahan bersifat positif dan aktif; 4) perubahan bukan bersikap sementara; 5) perubahan bertujuan dan terarah, serta 6) perubahan mencakup seluruh aspek tingkah laku. 
Nana Sudjana (2015: 39-40) menyebutkan faktor-faktor yang menentukan pencapaian hasil belajar antara lain : Faktor yang berasal dari dalam diri sisw yaitu faktor yang berasal dari dalam diri siswa misalnya kemampuan yang dimilikinya, motivasi belajar, minat dan perhatian, sikap dan kebiasaan belajar, ketekunan, sosial ekonomi, faktor fisik dan psikis dan Faktor yang berasal dari luar diri siswa atau faktor lingkungan yaitu kualitas pengajaran, yaitu efektif tidaknya proses belajar mengajar dalam mencapai tujuan pengajaran.

Metode tanya jawab dapat dinilai sebagai metode yang tepat, apabila pelaksanaannya ditujukan untuk: a) meninjau ulang pelajaran atau ceramah yang lalu agar peserta didik dapat memusatkan perhatiannya pada jenis dan jumlah kemajuan yang telah dicapai sehingga mereka dapat melanjutkan pelajarannya, b) menyelingi pembicaraan agar tetap mendapat perhatian peserta didik atau dengan perkataan lain untuk mengikutsertakan mereka, c) untuk mengarahkan pengamatan dan pemikiran mereka (H. Martinis Yamin, 2013: 154).

Metode tanya jawab multiarah menuntut perhatian atau pemusatan penelitian terhadap keberhasilan yang dipelajari sehingga dapat diketahui kemajuan siswa dalam belajar sebelum melanjutkan ke materi yang lain. Metode tanya jawab merupakan cara penyajian pelajaran dengan memberi pertanyaan-pertanyaan pada peserta didik untuk dijawab. Metode ini sangat berguna apabila mau memantapkan atau mengulang apa yang sudah dipelajari siswa untuk penguatan-penguatan. Metode ini juga berguna untuk menyelingi pembicaraan agar perhatian siswa tetap terpusat pada pelajaran. Metode ini sangat berguna untuk mengarahkan pengamatan peserta didik pada bagian-bagian penting dari materi. Metode ini menuntut pemikiaran siswa yang luas, berkesinambungan dan terarah sehingga hal-hal yang belum dimengerti tampak ke permukaan. Metode ini membantu memunculkan pendapatpendapat yang berbeda-beda dan membantu mengarahkan pada kelanjutan kegiatan seperti diskusi.

Pertanyaan yang diberikan oleh guru sebagai pemeran aktif pembelajaran harus juga dibarengi dengan menyuruh peserta didik untuk menyiapkan sebuah pertanyaan untuk ditanyakan pada teman-temannya. Cara ini akan menolong mengaktifkan peserta didik yang pasif atau yang selalu diam saja selama proses pembelajaran. Dengan menyuruh peserta didik menyebut satu pertanyaan dengan menulis di bukunya pertanyaan tersebut maka siswa kaan dituntut untuk membaca, memahami materi terlebih dahulu sebelum bisa menulis sebuah pertanyaan. Cara ini jarang dilakukan guru sehingga peneliti mencobanya.

Keuntungan dari metode tanya jawab adalah: a) guru mampu memahami kemajuan siswanya, b) guru dapat mengembangkan pertanyaan ke arah hal-hal yang belum dihampi betul dari materi yang diajar, c) tanya jawab multiarah membuat peserta didik yang semua diam saja akan bergiliran untuk menjawab pertanyaan yang disampaikan guru atau pertanyaan yang disampaikan siswa lain karena dalam tanya jawab multiarah satu pertanyaan bisa dilemparkan pada siswa yang diam saja.

\section{METODE PENELITIAN}

Pengambilan lokasi penelitian yang ditentukan adalah di kelas XI.IPS 1 semester II tahun pelajaran 2019/2020 SMA Negeri 1 Kuta. Pihak sekolah sudah berupaya semaksimal mungkin agar lingkungan sekolah aman, nyaman, bersih sebagai upaya mendukung pelaksanaan pembelajaran sesuai harapan. Rancangan dalam penelitian ini dikutip dari model yang diadopsi dari Suharsimi Arikunto, Suhardjono, Supardi (2016:58) seperti dapat dilihat pada Gambar 1. 


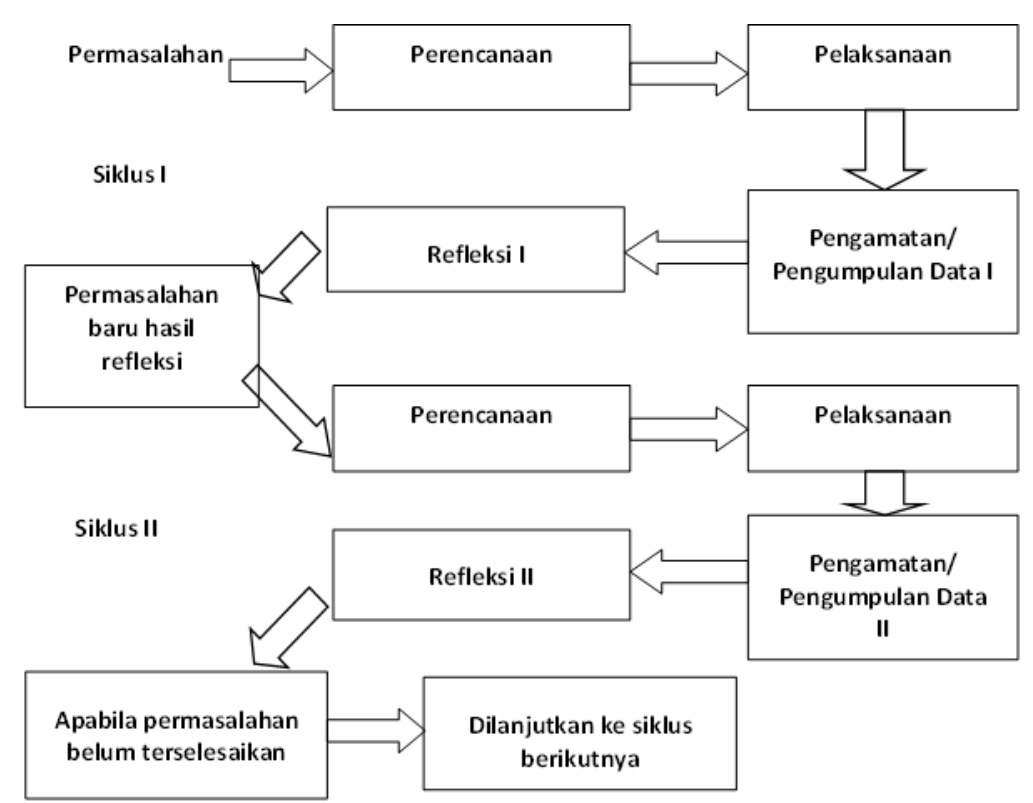

Gambar 1. Rancangan Penelitian

Subjek penelitian ditentukan karena ditemukannya permasalahan belum tuntasnya prestasi belajar sesuai yang diharapkan. Permasalahan tersebut ditemukan pada siswa kelas XI.IPS 1 semester II tahun pelajaran 2019/2020 SMA Negeri 1 Kuta, sehingga dipilih menjadi subjek dalam penelitian ini. Penentuan objek penelitian ini adalah peningkatan prestasi belajar Sosiologi siswa kelas XI.IPS 1 semester II tahun pelajaran 2019/2020 SMA Negeri 1 Kuta. Untuk penelitian ini akan dilangsungkan dari bulan Januari sampai bulan Mei tahun 2020. Untuk mengukur tingkat keberhasilan tindakan yang telah dilakukan guru maka dilakukan dengan kegiatan observasi. Observasi dilakukan menggunakan tes prestasi belajar. Melalui tes prestasi belajar, semuadata yang telah dikumpulkan selanjutnya dianalisis untuk mendapatkan gambaran yang jelas tentang tingkat keberhasilan yang telah dicapai. Analisis data dilakukan secara deskriptif.

\section{HASIL DAN PEMBAHASAN}

Data yang diperoleh dari prestasi belajar Sosiologi kegiatan awal yang dilakukan pada siswa kelas XI.IPS 1 semester II tahun pelajaran 2019/2020 SMA Negeri 1 Kuta adalah 22 siswa $(61,11 \%)$ memperoleh nilai di bawah KKM, 9 siswa $(25,00 \%)$ memperoleh nilai ratarata KKM dan selebihnya yaitu 5 siswa $(13,89 \%)$ memperoleh nilai di atas KKM. Hasil yang cukup rendah ini tidak terlepas dari kegiatan yang dilakukan guru yang belum profesional. Guru masih mengajar sekehendak hati, belum menyiapkan segala sesuatunya dengan baik, belum melihat dan belum membaca teori-teori para ahli yang benar, masih tradisional dan konvensional. Dengan ketidakberhasilan tersebut maka guru sebagai praktisi dituntut untuk lebih mampu membuat agar pembelajaran menjadi lebih konstruktivis, mengikuti kemajuan jaman dan mengajar dengan menggunakan metode yang lebih modern dan sesuai kebenaran teori para ahli.

Hasil yang diperoleh dari penilaian prestasi belajar Sosiologi siklus I yang sudah dilakukan yaitu ada 11 siswa $(30,56 \%)$ yang memperoleh nilai di bawah KKM, ada 16 $(44,44 \%)$ memperoleh nilai sama dengan KKM dan ada 9 (25,00\%) yang memperoleh nilai di atas KKM. Secara kuantitatif dapat diberikan analisis sebagai berikut : Rata-rata (mean): 69,92; Median (titik tengahnya): 70,00; Modus: 70,00. 
Tabel 1. Data Kelas Interval Siklus I

\begin{tabular}{ccccc}
\hline $\begin{array}{c}\text { No } \\
\text { Urut }\end{array}$ & Interval & $\begin{array}{c}\text { Nilai } \\
\text { Tepi }\end{array}$ & $\begin{array}{c}\text { Frekuensi } \\
\text { Absolut }\end{array}$ & $\begin{array}{c}\text { Frekuensi } \\
\text { Relatif }\end{array}$ \\
\hline 1 & $65-67$ & $64,5-67,5$ & 11 & $65-67$ \\
2 & $68-70$ & $67,5-70,5$ & 16 & $68-70$ \\
3 & $71-73$ & $70,5-73,5$ & 1 & $71-73$ \\
4 & $74-76$ & $73,5-76,5$ & 5 & $74-76$ \\
5 & $77-79$ & $76,5-79,5$ & 3 & $77-79$ \\
6 & $80-82$ & $79,5-82,5$ & 0 & $80-82$ \\
\hline & Total & & 36 & 100 \\
\hline
\end{tabular}

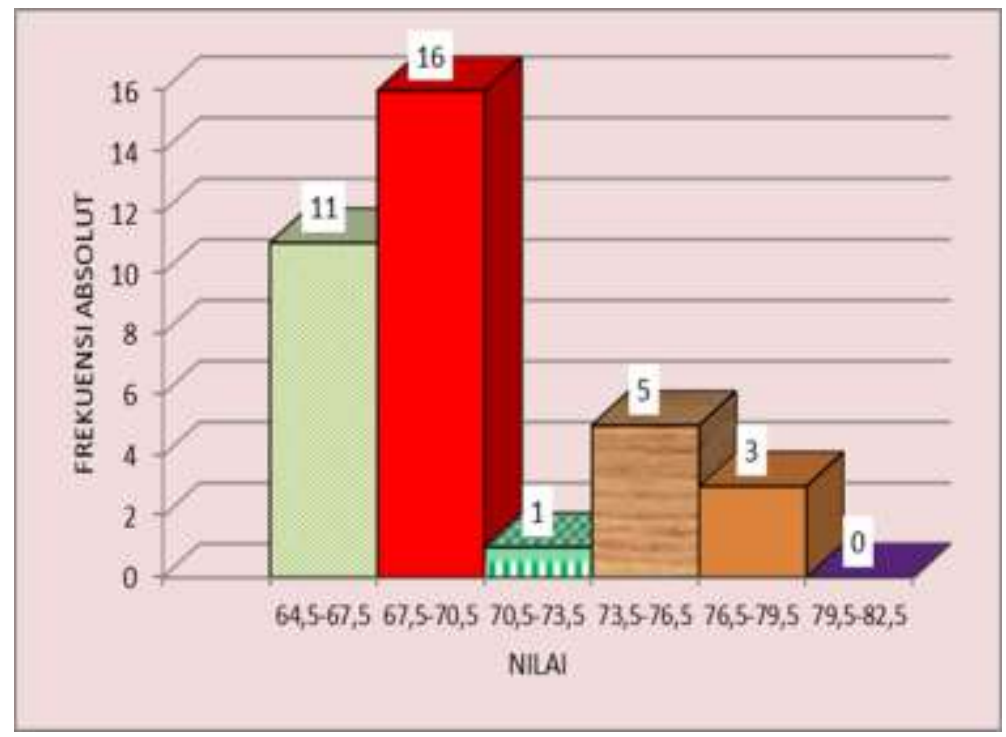

Gambar 2. Histogram Siklus I

Pada siklus II dalam hubungan dengan peningkatan prestasi belajar Sosiologi didapat ada 3 siswa (8,33\%) memperoleh nilai sama dengan KKM dan 33 siswa (91,67\%) memperoleh nilai di atas KKM. Artinya bahwa mereka berada pada kategori mampu memenuhi tuntutan yang diinginkan. Secara kuantitatif dapat diberikan analisis sebagai berikut : Rata-rata (mean): 81,36; Median (titik tengahnya): 82,00; Modus: 84,00

Tabel 2. Data Kelas Interval Siklus II

\begin{tabular}{ccccc}
\hline $\begin{array}{c}\text { No } \\
\text { Urut }\end{array}$ & Interval & $\begin{array}{c}\text { Nilai } \\
\text { Tepi }\end{array}$ & $\begin{array}{c}\text { Frekuensi } \\
\text { Absolut }\end{array}$ & $\begin{array}{c}\text { Frekuensi } \\
\text { Relatif }\end{array}$ \\
\hline 1 & $70-74$ & $69,5-74,5$ & 3 & 8,33 \\
2 & $75-79$ & $74,5-79,5$ & 9 & 25,00 \\
3 & $80-84$ & $79,5-84,5$ & 15 & 41,67 \\
4 & $85-89$ & $84,5-89,5$ & 5 & 13,89 \\
5 & $90-94$ & $89,5-94,5$ & 2 & 5,56 \\
6 & $95-99$ & $94,5-99,5$ & 2 & 5,56 \\
\hline \multicolumn{5}{r}{ Total } \\
\hline
\end{tabular}




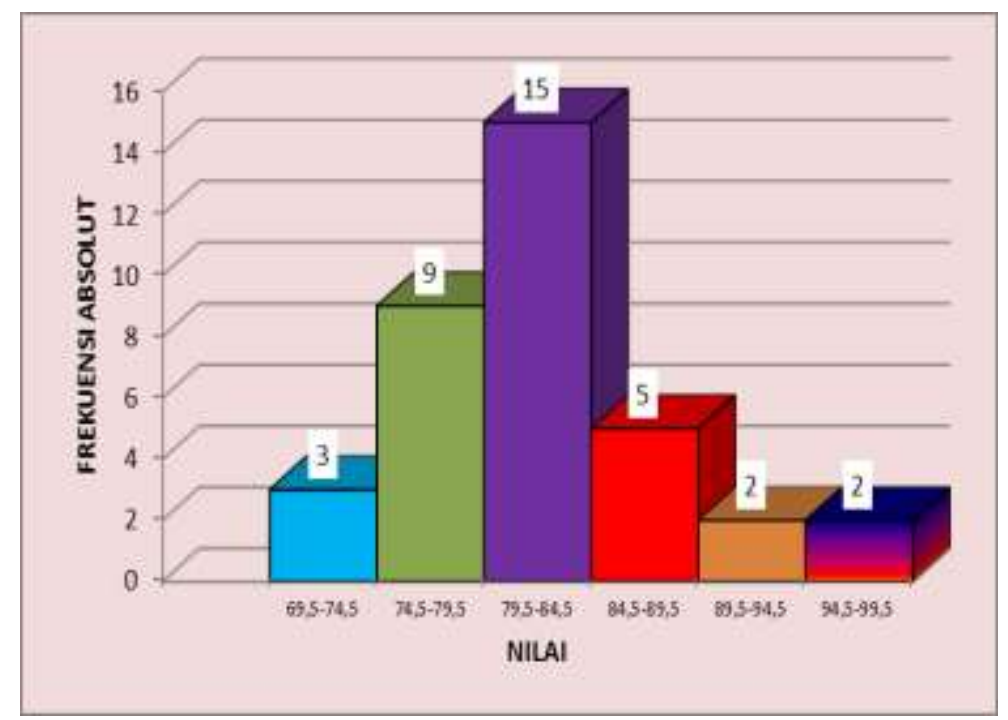

Gambar 3. Histogram Siklus II

\section{KESIMPULAN DAN SARAN}

Simpulan yang dapat disampaikan sesuai fakta yang diperoleh dari pelaksanaan kegiatan penelitian adalah pemanfaatan metode tanya jawab multiarah telah dapat membuktikan bahwa guru dan siswa menjadi sangat aktif dalam pembelajaran, mampu membuat pembelajaran menjadi bermakna, mudah diterima, mampu melakukan pembelajaran tuntas dan siswa dapat memahami pembelajaran dengan lebih baik dan mampu mengendap lebih lama ilmu yang telah diperoleh. Semua fakta di atas dapat dibuktikan dengan data: Nilai rata-rata awal 65,83 naik menjadi 69,92 pada siklus I dan pada siklus II naik menjadi 81,36. Pada kegiatan awal siswa yang belum tuntas sebanyak 22 siswa $(61,11 \%)$, pada siklus I menurun menjadi 11 siswa (30,56\%) kemudian pada siklus II tidak ada siswa (0\%) memperoleh nilai di bawah KKM. Pada kegiatan awal siswa yang tuntas sebanyak 14 siswa $(38,89 \%)$ pada siklus I meningkat menjadi 25 siswa $(69,44 \%)$ kemudian pada siklus II seluruh siswa sebanyak 36 orang siswa (100\%) dinyatakan tuntas. Jadi dapat disimpulkan bahwa pemanfaatan metode tanya jawab multiarah dapat meningkatkan prestasi belajar Sosiologi siswa kelas XI.IPS 1 semester II tahun pelajaran 2019/2020 SMA Negeri 1 Kuta.

Dengan telah berhasilnya penelitian ini maka, disampaikan saran-saran sebagai berikut: 1) Kepada teman guru pengajar disarankan untuk mencoba metode tanya jawab multiarah. 2) Kepada kepala sekolah disarankan untuk memberi penekanan agar guru mau melaksanakan pembelajaran dengan langkah-langkah metode yang sudah diteliti. 3) Walaupun penelitian ini sudah dapat membuktikan efek utama dari metode tanya jawab multiarah dalam meningkatkan prestasi belajar, sudah pasti dalam penelitian ini masih ada hal-hal yang belum sempurna dilakukan, oleh karenanya kepada peneliti lain yang berminat meneliti topik yang sama untuk meneliti bagian-bagian yang tidak sempat diteliti. 4) Selanjutnya untuk adanya penguatan-penguatan, diharapkan bagi peneliti lain untuk melakukan penelitian lanjutan guna verifikasi data hasil penelitian.

\section{UCAPAN TERIMAKASIH}

Ucapan terima kasih disampaikan kepada Kepala SMA Negeri 1 Kuta dan Bapak/Ibu Guru SMA Negeri 1 Kuta 


\section{DAFTAR PUSTAKA}

Djiwandono, Sri Esti Wuryani. 2016. Psikologi Pendidikan (Rev-2). Penerbit: Grasindo. Jakarta.

Hamalik, Oemar. 2015. Kurikulum dan Pembelajaran. Jakarta: PT. Bumi Aksara.

Nana Sudjana, 2015. Penilaian Hasil Proses Belajar Mengajar. Bandung: PT Remaja Rosdakarya.

Qory, Aina. 2015. Hubungan Dukungan Sosial Teman Sebaya dengan Penyesuaian Sosial pada Siswa Akselerasi Bina Insani. Skripsi UPI Bandung. Tidak Diterbitkan.

Slameto. 2014. Belajar dan Faktor-Faktor yang Mempengaruhinya. Jakarta : PT. Rineka Cipta.

Sukidin, Basrowi, Suranto. 2002. Menajemen Penelitian Tindakan Kelas. Penerbti: Insan Cendekia ISBN: 9799048334.

Tjundjing, Sia. 2016. Hubungan Antara IQ, EQ, dan QA dengan Prestasi Studi pada Siswa SMU. Jurnal Anima Vol. 17. No.1.

Yamin, H. Martinis. 2013. Strategi dan Metode dalam Model Pembelajaran. Jakarta: Referensi (G. P. Press Group). 